\title{
Characterization of the indigenous microflora in raw and pasteurized buffalo milk during storage at refrigeration temperature by high-throughput sequencing
}

\author{
Ling Li, ${ }^{*}$ John A. Renye Jr.,† Ling Feng, ${ }^{*}$ Qingkun Zeng, ${ }^{* 1}$ Yan Tang, ${ }^{\text {Li Huang, }{ }^{*} \text { Daxi Ren, } \ddagger \text { and Pan Yang }}$ \\ *Buffalo Research Institute, Chinese Academy of Agricultural Science, Nanning, Guangxi 530002, P. R. China \\ †Dairy and Functional Foods Research Unit, Eastern Regional Research Center (ERRC), Agricultural Research Service (ARS), \\ Wyndmoor, PA 19038 \\ łlnstitute of Dairy Science, College of Animal Sciences, Zhejiang University, Hangzhou, Zhejiang 310029, P. R. China
}

\section{ABSTRACT}

The effect of refrigeration on bacterial communities within raw and pasteurized buffalo milk was studied using high-throughput sequencing. High-quality samples of raw buffalo milk were obtained from 3 dairy farms in the Guangxi province in southern China. Five liters of each milk sample were pasteurized $\left(72^{\circ} \mathrm{C} ; 15\right.$ s); and both raw and pasteurized milks were stored at refrigeration temperature $\left(1-4^{\circ} \mathrm{C}\right)$ for various times with their microbial communities characterized using the Illumina Miseq platform (Novogene, Beijing, China). Results showed that both raw and pasteurized milks contained a diverse microbial population and that the populations changed over time during storage. In raw buffalo milk, Lactococcus and Streptococcus dominated the population within the first $24 \mathrm{~h}$; however, when stored for up to $72 \mathrm{~h}$ the dominant bacteria were members of the Pseudomonas and Acinetobacter genera, totaling more than $60 \%$ of the community. In pasteurized buffalo milk, the microbial population shifted from a Lactococcus-dominated community (7 d), to one containing more than $84 \%$ Paenibacillus by 21 d of storage. To increase the shelf-life of buffalo milk and its products, raw milk needs to be refrigerated immediately after milking and throughout transport, and should be monitored for the presence of Paenibacillus. Results from this study suggest pasteurization should be performed within $24 \mathrm{~h}$ of raw milk collection, when the number of psychrotrophic bacteria are low; however, as Paenibacillus spores are resistant to pasteurization, additional antimicrobial treatments may be required to extend shelf-life. The findings from this study are expected to aid in improving the quality and safety of raw and pasteurized buffalo milk.

Key words: high-throughput DNA sequencing, buffalo milk, refrigeration storage, indigenous microflora

Received February 17, 2016.

Accepted May 24, 2016.

${ }^{1}$ Corresponding author: zqk456@163.com

\section{INTRODUCTION}

China ranks third in the world with regard to its number of dairy buffalo herds and the production of buffalo milk. Within the subtropical south of China, the buffalo farming system has traditionally consisted of both commercial-scale and individual farms from which raw milk is pooled and stored at refrigeration temperature $\left(1-4^{\circ} \mathrm{C}\right)$ for up to $24 \mathrm{~h}$ before being transferred to dairy plants. This results in raw milk being stored for between 24 and $48 \mathrm{~h}$ before processing and pasteurization. Although low storage temperatures $\left(\leq 4^{\circ} \mathrm{C}\right)$ reduce the growth of many bacteria, they can select for the growth of psychrotrophic bacteria known to cause spoilage of bovine milk (Champagne et al., 1994; DeJonghe et al., 2011; Reche et al., 2015). In addition, pasteurization is used to reduce the microbial load of milk, but the lysis of psychrotrophic bacteria may lead to the release of heat resistant proteolytic and lipolytic enzymes that could affect the shelf life of milk and dairy products such as cheeses and milk powders. A previous study showed that heat-resistant proteolytic enzymes from psychrotrophic bacteria could result in the degradation of cheese caseins, resulting in a reduced cheese yield (Mankai et al., 2012), whereas another report showed that raw goat milk should not be stored for more than $3 \mathrm{~d}$ at $4^{\circ} \mathrm{C}$ after heat treatment or the presence of lipolytic enzymes will reduce the quality of milk powder, which typically has a shelf-life of 180 d (Fonseca et al., 2013). In addition, gram-positive spore-forming bacteria are also known to contribute to milk spoilage, as they may survive heat treatments and become a dominant population within the microflora of pasteurized milk (Ranieri et al., 2009).

Microbial populations in raw milk are important for the quality of resulting dairy products. Culture-independent sequencing technology has been widely used in the analysis of microbial diversity within raw milk and dairy products, and could be used to determine the presence of harmful and beneficial bacteria (Delgado et al., 2013; Weber et al., 2014). The microflora of raw 
milk has been reported to change depending on the location of the herd, breeding practices, and lactation period. The specific composition of the milk microbiota directly affects the subsequent development of dairy products. However, the microbiota within raw and pasteurized Chinese water buffalo milk during refrigerated storage $\left(\leq 4^{\circ} \mathrm{C}\right)$ has not been investigated. Therefore, the aim of the current study was to analyze shifts within the bacterial communities in raw and pasteurized buffalo milk during prolonged storage at refrigeration temperature and determine the dominant populations that may affect the quality and safety of the milk and resulting dairy products.

\section{MATERIALS AND METHODS}

\section{Collection and Treatment of Milk Samples}

Raw buffalo milk was obtained from 3 different dairy farms, with herds ranging from 50 to 1,000 buffalo. Farms were all located within the Guangxi province of China, ensuring that buffalo herds were raised in a similar subtropical climate with an average annual temperature of $21.6^{\circ} \mathrm{C}\left(70.9^{\circ} \mathrm{F}\right)$ and an average humidity of $\sim 79 \%$. Raw milk was immediately cooled to $4^{\circ} \mathrm{C}$ and maintained at this temperature during transport to the laboratory for analysis. Total bacterial counts for each raw milk sample were below $300,000 \mathrm{cfu} / \mathrm{mL}$, and the SCC were below 200,000 cells/mL. Raw milk samples were stored at 1 to $4^{\circ} \mathrm{C}$ for $2,24,48$, and 72 $\mathrm{h}$ before freezing at $-20^{\circ} \mathrm{C}$ (Table $1: \mathrm{R}_{2}, \mathrm{R}_{24}, \mathrm{R}_{48}$, and $\mathrm{R}_{72}$, respectively). The average fat content of the raw buffalo milk samples was $6.87 \pm 0.62 \mathrm{~g} / 100 \mathrm{~g}$ of milk; thus, HTST pasteurization was performed at $72^{\circ} \mathrm{C}$ for 1 $5 \mathrm{~s}$. Following pasteurization, the milk samples were immediately cooled to $4^{\circ} \mathrm{C}$. The pasteurized milk samples were then stored at 1 to $4^{\circ} \mathrm{C}$ for 7,14 , or $21 \mathrm{~d}$ (Table 1 : $\mathrm{P}_{7}, \mathrm{P}_{14}$, and $\mathrm{P}_{21}$, respectively) before freezing at $-20^{\circ} \mathrm{C}$. Time points consisted of 3 separate milk sets representing each of the 3 dairy herds sampled; thus, a total of 21 DNA samples were obtained and analyzed. Prior to DNA extraction all samples were stored at $-20^{\circ} \mathrm{C}$ and then defrosted at $4^{\circ} \mathrm{C}$.

\section{Extraction of DNA}

Bacteria obtained from $10-\mathrm{mL}$ milk samples were collected by centrifugation at $13,200 \times g$ for $15 \mathrm{~min}$ at $4^{\circ} \mathrm{C}$. Fat and cell-free supernatants were removed, and cells were washed with $10-\mathrm{mL}$ sterilized ultrapure water and centrifuged again at 13,200 $\times g$ for 5 min at $4^{\circ} \mathrm{C}$ to remove excess fat. Cells were resuspended in 2 $\mathrm{mL}$ of PBS, and $1.5 \mathrm{~mL}$ of the suspension was used for the preparation of total genomic DNA using the PowerFood Microbial DNA Isolation kit (MoBio Laboratories Inc., Carlsbad, CA) according to the manufacturer's instructions. An additional 10-min incubation step at $75^{\circ} \mathrm{C}$ was incorporated before step 5 of the kit, as described previously (Quigley et al., 2012). The purity and integrity of the extracted DNA was determined by spectrophotometric analysis with a Nanodrop 2000 (Thermo Fisher Scientific, Waltham, MA) and agarose gel electrophoresis, respectively.

\section{High-Throughput Sequencing and Bioinformatics Analysis}

The PCR amplifications were conducted with the 515f/806r primer set that amplifies the V4 region of the 16S rRNA gene (Caporaso et al., 2011). All PCR reactions were carried out in $30-\mu \mathrm{L}$ reactions with $15 \mu \mathrm{L}$ of Phusion High-Fidelity PCR Master Mix (New England BioLabs Inc., Ipswich, MA), $0.2 \mu M$ of forward and reverse primers, and approximately $10 \mathrm{ng}$ of template DNA. Thermal cycling consisted of initial denaturation at $98^{\circ} \mathrm{C}$ for $1 \mathrm{~min}$; followed by 30 cycles of denaturation at $98^{\circ} \mathrm{C}$ for $10 \mathrm{~s}$, annealing at $50^{\circ} \mathrm{C}$ for $30 \mathrm{~s}$, elongation at $72^{\circ} \mathrm{C}$ for $60 \mathrm{~s}$, and a final extension at $72^{\circ} \mathrm{C}$ for $5 \mathrm{~min}$. The reverse primer contained a 6 -bp errorcorrecting barcode unique to each sample. The pairedend sequencing was performed on an Illumina Miseq platform (Novogene, Beijing, China) based on a standard protocol from the manufacturer. Sequences were analyzed with QIIME (Caporaso et al., 2010) software package and UPARSE pipeline (Edgar, 2013). Pairs of reads from the original DNA fragments were merged using FLASH (Magoč and Salzbert, 2011), and filtered by QIIME quality filters. The percentage of tagged se-

Table 1. Time points when milk samples were collected for analysis of the indigenous microflora

\begin{tabular}{lc}
\hline Item & Refrigerated storage time \\
\hline Raw milk $^{1}$ samples $(\mathrm{h})$ & \\
$\mathrm{R}_{2}$ & 2 \\
$\mathrm{R}_{24}$ & 24 \\
$\mathrm{R}_{48}$ & 48 \\
$\mathrm{R}_{72}$ & 72 \\
Pasteurized milk $^{2}$ samples (d) & \\
$\mathrm{P}_{7}$ & 7 \\
$\mathrm{P}_{14}$ & 14 \\
$\mathrm{P}_{21}$ & 21
\end{tabular}

${ }^{1}$ Raw milk samples were collected from 3 different farms and stored at 1 to $4^{\circ} \mathrm{C}$ for $2,24,48$, and $72 \mathrm{~h}\left(\mathrm{R}_{2}, \mathrm{R}_{24}, \mathrm{R}_{48}\right.$, and $\mathrm{R}_{72}$, respectively).

${ }^{2}$ The $\mathrm{R}_{2}$ samples from each farm were pasteurized at $72^{\circ} \mathrm{C}$ for $15 \mathrm{~s}$, cooled to $4^{\circ} \mathrm{C}$, and stored at 1 to $4^{\circ} \mathrm{C}$ for 7,14 , and $21 \mathrm{~d}$, respectively $\left(\mathrm{P}_{7}, \mathrm{P}_{14}\right.$, and $\mathrm{P}_{21}$, respectively). In total, 21 DNA samples were obtained. All samples were analyzed by high-throughput sequencing. 
quences used for analysis is shown in Table 2 [Effective $\%=(\mathrm{E} \times 100) / \mathrm{R}$; where $\mathrm{E}=$ number of effective tags and $\mathrm{R}=$ total number of raw pair end reads]. Default settings for Illumina processing in QIIME were used and the UPARSE pipeline was used to generate operational taxonomic units (OTU). The Phred quality score (Q score) was used to evaluate the read quality; for each sample $\geq 96 \%$ of the reads exceeded a quality score of Q30 (error probability of $<1 / 1,000$; Table 2 ). Sequences were assigned to OTU at $97 \%$ similarity. A representative sequence was picked for each OTU. The RDP classifier (Wang et al., 2007) was used to assign each OTU to a taxonomic level. Bacterial clustering was analyzed at phylum and genus level, and to reveal alpha diversity QIIME was used to generate rarefaction curves, Shannon-Wiener and Chao1 diversity indices, and Good's coverage estimator values. Good's coverage $[1-$ (number of singleton OTU/total number of individuals)] was used to evaluate the sequencing depth. Sufficient sequencing depth is represented by a value near 1, and all samples analyzed in our study had Good's coverage values between 0.974 and 0.995 (Table 2). All data shown represents the mean $( \pm \mathrm{SD})$ of sequencing results obtained from 3 individual milk samples at each time point (21 milk samples were analyzed in total). The 3 samples represent milk collected form each buffalo dairy herd used in the study.

\section{Statistical Analysis}

Data were analyzed by SPSS 17.0 software (IBM Corp., Armonk, NY), with multiple comparisons made using the Least Significant Difference (LSD) method at a 0.05 level.

\section{RESULTS}

\section{Quality Control and Diversity Analysis}

Rarefaction analysis revealed that the overall depth of sequencing was sufficient, and that sample diversity decreased during prolonged storage under refrigeration conditions $\left(1-4^{\circ} \mathrm{C}\right)$, with the 2 -h raw milk $\left(\mathrm{R}_{2}\right)$ and 7 -d pasteurized milk $\left(\mathrm{P}_{7}\right)$ samples displaying higher species diversities (Figure 1). Quality control, diversity, and richness estimations for each group are shown in Table 2 . The number of clean reads increased significantly $(P$ $<0.05)$ in raw milk samples during cold storage, from $49,079\left(\mathrm{R}_{2}\right)$ to 99,513 after $48 \mathrm{~h}\left(\mathrm{R}_{48}\right)$. The Shannon and Chaol diversity indices also decreased significantly during storage $(P<0.05)$, further confirming the presence of a less-diverse microflora. A transition to a less-diverse microflora was also observed in pasteurized milk samples where the number of clean reads increased after $21 \mathrm{~d}$ of cold storage $(P<0.05)$, and both the Shannon and Chao 1 diversity indices decreased by 14 d of storage (Table 2).

\section{Bacterial Community Composition of Raw Milk}

The microbial population of raw buffalo milk during storage at 1 to $4^{\circ} \mathrm{C}$ was investigated at both the phyla (Figure 2A) and genus levels (Figure 2B). In addition, a more precise percentage of the bacterial composition present at more than $1 \%$ of the total population is reported in Table 3 . After $2 \mathrm{~h}$ of storage at $4^{\circ} \mathrm{C}$, the raw milk was dominated by bacteria within the Firmicutes and Proteobacteria phyla, with each comprising more than $40 \%$ of the total population (Table 3 ). Following 24

Table 2. High-throughput sequencing quality control and bacteria diversity indices

\begin{tabular}{|c|c|c|c|c|c|}
\hline Index & $\mathrm{R}_{2}$ & $\mathrm{R}_{24}$ & $\mathrm{R}_{48}$ & $\mathrm{R}_{72}$ & $P$-value \\
\hline \multicolumn{6}{|l|}{ Bacteria of raw milk ${ }^{1}$} \\
\hline Clean reads & $49,079 \pm 99^{\mathrm{c}}$ & $55,225 \pm 6,029^{\mathrm{c}}$ & $99,513 \pm 27,851^{\mathrm{b}}$ & $179,519 \pm 27,658^{\mathrm{a}}$ & 0.000 \\
\hline Effective (\%) & $91.41 \pm 0.93^{\mathrm{a}}$ & $90.39 \pm 2.05^{\mathrm{a}}$ & $90.40 \pm 1.71^{\mathrm{a}}$ & $90.21 \pm 1.49^{\mathrm{a}}$ & 0.722 \\
\hline Q30 (\%) & $97.34 \pm 0.32^{\mathrm{b}}$ & $97.66 \pm 0.14^{\mathrm{ab}}$ & $97.71 \pm 0.08^{\mathrm{a}}$ & $97.70 \pm 0.16^{\mathrm{ab}}$ & 0.137 \\
\hline Good's coverage & $0.979 \pm 0.005^{\mathrm{b}}$ & $0.990 \pm 0.004^{\mathrm{a}}$ & $0.994 \pm 0.001^{\mathrm{a}}$ & $0.995 \pm 0.002^{\mathrm{a}}$ & 0.002 \\
\hline Shannon diversity & $6.94 \pm 1.09^{\mathrm{a}}$ & $4.76 \pm 1.60^{\mathrm{b}}$ & $3.93 \pm 0.28^{\mathrm{b}}$ & $3.67 \pm 0.16^{\mathrm{b}}$ & 0.018 \\
\hline \multirow[t]{2}{*}{ Chao1 diversity } & $2,133 \pm 687^{\mathrm{a}}$ & $978 \pm 326^{\mathrm{b}}$ & $531 \pm 81^{\mathrm{b}}$ & $501 \pm 195^{\mathrm{b}}$ & 0.003 \\
\hline & $\mathrm{R}_{2}$ & $\mathrm{P}_{7}$ & $\mathrm{P}_{14}$ & $\mathrm{P}_{21}$ & \\
\hline \multicolumn{6}{|c|}{ Bacteria of pasteurized milk ${ }^{2}$} \\
\hline Clean reads & $49,079 \pm 99^{\mathrm{b}}$ & $49,379 \pm 8,162^{\mathrm{b}}$ & $73,068 \pm 9,558^{\mathrm{b}}$ & $155,508 \pm 45,246^{\mathrm{a}}$ & 0.002 \\
\hline Effective (\%) & $91.41 \pm 0.93^{\mathrm{a}}$ & $88.32 \pm 0.80^{\mathrm{b}}$ & $89.42 \pm 1.92^{\mathrm{ab}}$ & $90.74 \pm 1.74^{\mathrm{ab}}$ & 0.074 \\
\hline Q30 (\%) & $97.34 \pm 0.32^{\mathrm{ab}}$ & $96.99 \pm 0.48^{\mathrm{b}}$ & $97.65 \pm 0.03^{\mathrm{a}}$ & $97.64 \pm 0.10^{\mathrm{a}}$ & 0.068 \\
\hline Good's coverage & $0.979 \pm 0.005^{\mathrm{bc}}$ & $0.974 \pm 0.008^{\mathrm{c}}$ & $0.986 \pm 0.003^{\mathrm{ab}}$ & $0.995 \pm 0.003^{\mathrm{a}}$ & 0.006 \\
\hline Shannon diversity & $6.94 \pm 1.09^{\mathrm{a}}$ & $7.51 \pm 1.29^{\mathrm{a}}$ & $4.36 \pm 0.69^{\mathrm{b}}$ & $1.95 \pm 0.11^{\mathrm{c}}$ & 0.000 \\
\hline Chao1 diversity & $2,133 \pm 687^{\mathrm{ab}}$ & $2,586 \pm 767^{\mathrm{a}}$ & $1,294 \pm 313^{\mathrm{bc}}$ & $500 \pm 221^{\mathrm{c}}$ & 0.007 \\
\hline
\end{tabular}

\footnotetext{
${ }^{\mathrm{a}-\mathrm{c}}$ Mean values with a different superscript differ by $P<0.05$.

${ }^{1}$ Mean of raw milk samples from 3 different farms stored at $4^{\circ} \mathrm{C}$ for $2,24,48$, or $72 \mathrm{~h}\left(\mathrm{R}_{2}, \mathrm{R}_{24}, \mathrm{R}_{48}\right.$, and $\mathrm{R}_{72}$, respectively).

${ }^{2}$ Pasteurized milk samples were stored at $4^{\circ} \mathrm{C}$ for 7,14 , and $21 \mathrm{~d}\left(\mathrm{P}_{7}, \mathrm{P}_{14}\right.$, and $\mathrm{P}_{21}$, respectively).
} 
h of storage, the number of Firmicutes increased significantly $(P<0.05)$, but then their numbers dropped after $72 \mathrm{~h}$ of storage to levels similar to the 2 -h sample $\left(\mathrm{R}_{2}\right.$; Figure 2A; Table 3). The abundance of Proteobacteria significantly decreased $(P<0.05)$ following $24 \mathrm{~h}$ of cold storage, but then recovered and was observed to be the dominant phyla in raw milk stored for $72 \mathrm{~h}$ (Figure 2A; Table 3). The Bacteroidetes population within raw milk remained constant throughout the study, whereas the Actinobacteria population appeared to decline gradually, with the population difference observed between the $\mathrm{R}_{2}$ and $\mathrm{R}_{72}$ samples being statistically significant (Table $3)$. At the genus level, the 3 dominant populations after $2 \mathrm{~h}$ were Streptococcus (14.20\%), Lactococcus (8.20\%), and Pseudomonas (4.93\%). After 24 h, Lactococcus and Streptococcus populations increased significantly ( $P$ $<0.05$ ), with the Lactococcus population comprising $38.6 \%$ of the total microflora. The percentage of lactococci and streptococci decreased as the milk was stored for 48 and $72 \mathrm{~h}$, with their respective percentages at $72 \mathrm{~h}$ being similar to $2 \mathrm{~h}$ of storage (Table 3 ). Prolonged storage at refrigeration temperatures resulted in a significant increase in Pseudomonas $(P<0.05)$, which represented the dominant genus after $72 \mathrm{~h}$ (Figure $2 \mathrm{~B}$ ) of storage, accounting for more than $51 \%$ of total bacteria (Table 3). In addition, the presence of bacteria within the Acinetobacter genus increased from $1.4\left(\mathrm{R}_{2}\right)$ to $11.2 \%\left(\mathrm{R}_{72}\right)$ during the course of the study, meaning the total proportion of Pseudomonas and Acinetobacter was $62 \%$ after $72 \mathrm{~h}$ of storage (Table 3 ).

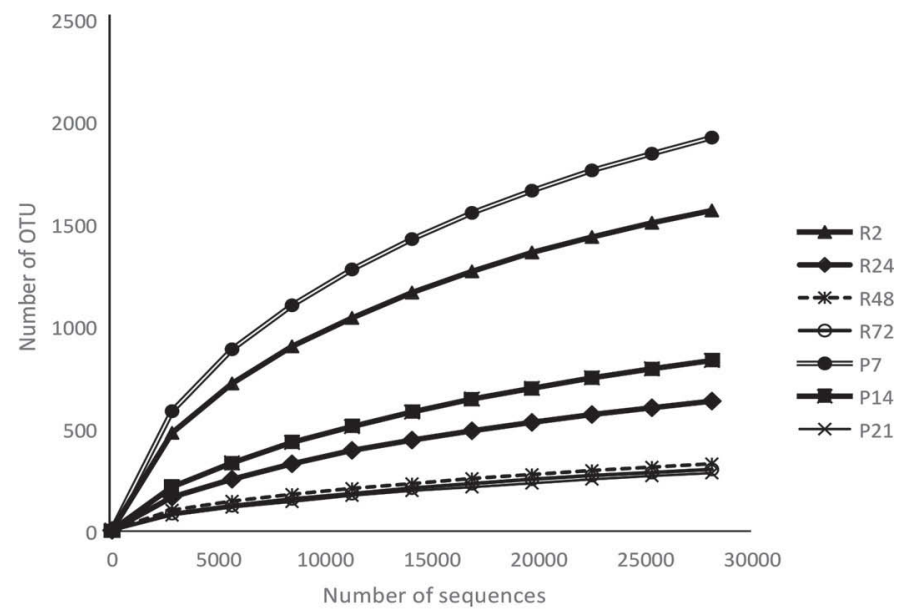

Figure 1. Rarefaction analysis at the $97 \%$ sequence similarity level. Raw and pasteurized milk samples were stored at $4^{\circ} \mathrm{C}$ for various times before rarefaction analysis: $R_{2}=$ raw milk samples stored for $2 \mathrm{~h}, \mathrm{R}_{24}$ $=$ raw milk samples stored for $24 \mathrm{~h}, \mathrm{R}_{48}=$ raw milk samples stored for $48 \mathrm{~h}, \mathrm{R}_{72}=$ raw milk samples stored for $72 \mathrm{~h}, \mathrm{P}_{7}=$ pasteurized milk samples stored for $7 \mathrm{~d}, \mathrm{P}_{14}=$ pasteurized milk samples stored for 14 $\mathrm{d}, \mathrm{P}_{21}=$ pasteurized milk samples stored for $21 \mathrm{~d}$. OTU $=$ operational taxonomic units.

\section{High-Throughput Sequencing of Pasteurized Milk}

Metagenomic analysis of the indigenous microflora in pasteurized buffalo milk was performed at the phyla (Figure 3A) and genus levels (Figure 3B). The percent change for bacteria present at higher than $1 \%$ of the total population is shown in Table 4. Although we found no significant population changes when looking at bacterial phyla in pasteurized milk stored for $7 \mathrm{~d}$, analysis at the genus level showed a statistically significant increase in the percentage of lactococci and decrease in the percentage of streptococci at this time point $\left(\mathrm{P}_{7}\right.$; Table 4). Firmicutes and Proteobacteria were the dominant phyla present at $7 \mathrm{~d}$ of storage, representing more than $90 \%$ of the total population (Table 4); however, by $14 \mathrm{~d}$ of storage the percentage of Proteobacteria began to decrease and the number of Firmicutes significantly increased (Figure 3A; Table 4). After $21 \mathrm{~d}$ of storage it was observed that the Firmicutes were the dominant phyla at more than $90 \%$ of the total population (Table 4 ); this coincided with a significant increase in the number of Paenibacillus present, which reached more than $80 \%$ of the total microbial composition (Figure 3B; Table 4). The percentages of other bacterial genera shown in Table 4 decreased after $21 \mathrm{~d}$ of cold storage, with the exception of Acinetobacter, which remained constant at approximately $1 \%$ of the total population (Figure 3B).

\section{DISCUSSION}

In our study, $16 \mathrm{~S}$ rRNA profiling provided detailed insights into the complex microbiota of raw and pasteurized buffalo milk. Our results showed that both raw and pasteurized milk contained a diverse microbial population, which underwent significant changes during prolonged storage at refrigeration temperature. Diversity index analysis indicated that the population within both raw and pasteurized milk gradually decreased with longer storage times, with the raw milk stored for $2 \mathrm{~h}\left(\mathrm{R}_{2}\right)$ and pasteurized milk stored for $7 \mathrm{~d}\left(\mathrm{P}_{7}\right)$ containing the most diverse microbial populations. In both milks, the populations became significantly less diverse over time, presumably due to the growth of psychrotrophic bacteria. However, the dominant bacterial phyla differed between milk samples at the final time point analyzed, with Proteobacteria comprising more than $60 \%$ of the raw milk population and Firmicutes making up more than $90 \%$ of the pasteurized milk microflora.

A previous study showed that the main bacteria phyla present in raw cow milk were Firmicutes, Proteobacteria, Actinobacteria, and Bacteroidetes as detected by 16S rRNA sequencing (Zhang et al., 2015). A separate study found similar results with these phyla making up 


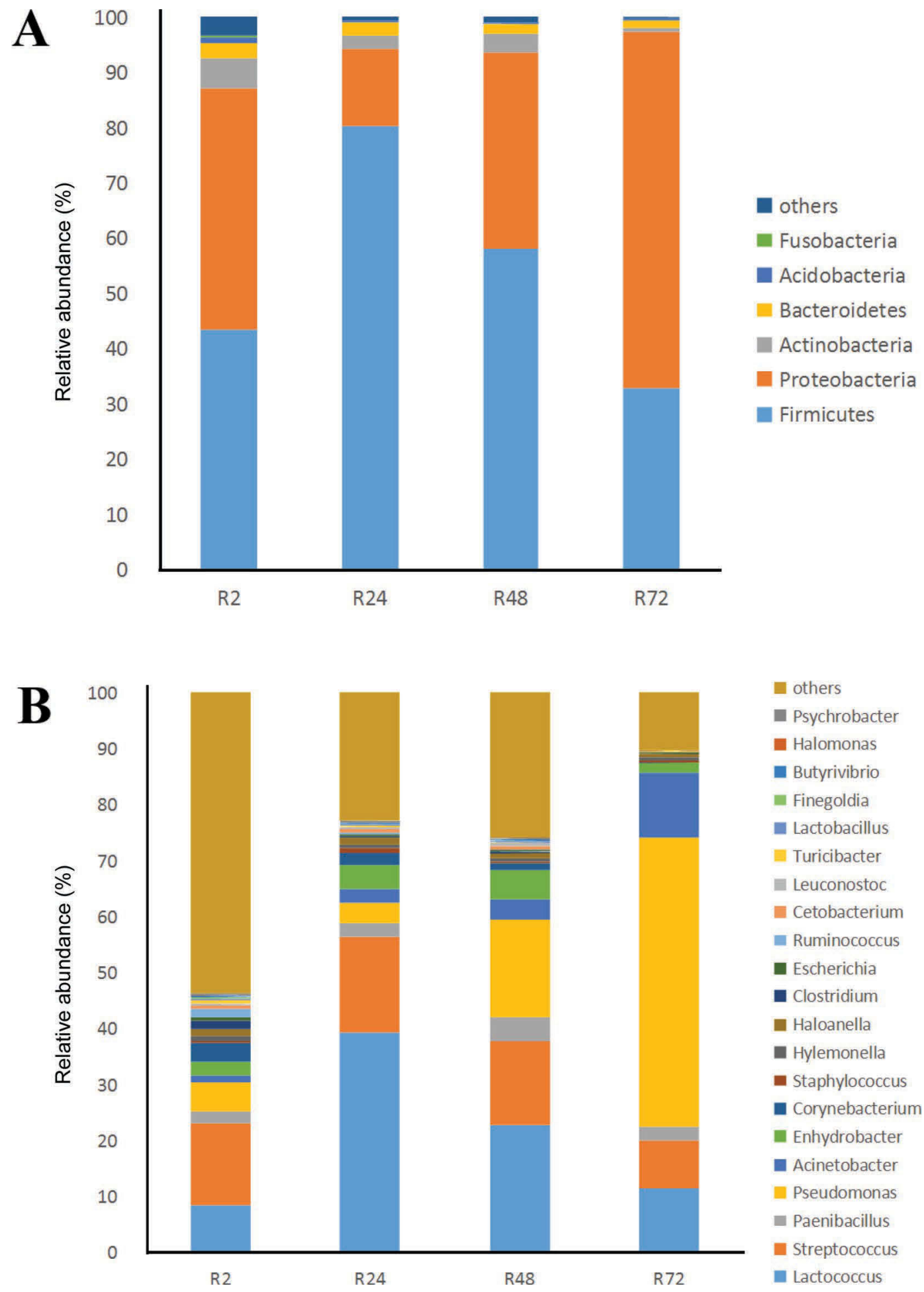

Figure 2. Composition of the indigenous microflora, at the phyla (A) and genus (B) levels, in raw milk samples stored under refrigerated temperatures. Data represent the mean percentage from the metagenomics analysis of 3 separate raw milk samples. $R_{2}=$ raw milk samples stored for $2 \mathrm{~h}, \mathrm{R}_{24}=$ raw milk samples stored for $24 \mathrm{~h}, \mathrm{R}_{48}=$ raw milk samples stored for $48 \mathrm{~h}, \mathrm{R}_{72}=$ raw milk samples stored for $72 \mathrm{~h}$. 
$58,22,17$, and $4 \%$, respectively, of the total microflora in bovine milk (Delbès et al., 2007). Results from our study identified the same 4 bacterial phyla dominating the microflora of raw buffalo milk; however, the relative abundance of Proteobacteria and Firmicutes were similar in buffalo milk at $\sim 43 \%$, and the amount of Actinobacteria was significantly lower at $5 \%$ of the total population.

Culturing the indigenous microflora of raw ovine milk suggested that lactococci comprise a dominant population in fresh milk, including being more prevalent than Pseudomonas (Sanjuan et al., 2003). Similarly, raw bovine milk contained a more diverse microbiota when fresh, with lactococci and streptococci being the dominant genera (Raats et al., 2011). When stored for more than $54 \mathrm{~h}$ in a dairy plant tank at refrigerated temperature the microbial population shifted, with Pseudomonas and Acinetobacter becoming more dominant. This agreed with the findings of this study reported in Table 3, where streptococci and lactococci dominated the bacterial composition in raw buffalo milk stored for up to $24 \mathrm{~h}$. Prolonged storage resulted in a population shift in which psychrotolerant microorganisms, specifically Pseudomonas and Acinetobacter, became the predominant microorganisms (Table 3 ). The presence of high numbers of psychrotrophic bacteria has been considered the most common cause of milk spoilage (Sorhaug and Stepaniak, 1997; Hantsis-Zacharov and Halpern, 2007; Ercolini et al., 2009), with Pseudomonas reported to cause milk fat rancidity, color changes, and a bitter flavor (Ranieri et al., 2009; DeJonghe et al., 2011).

Whereas bacteria in the Pseudomonas and Acinetobacter genera dominated the microflora in cold-stored raw milk, their populations were not observed to in- crease in pasteurized buffalo milk stored for up to 21 d (Table 4). It is presumed that their lack of growth was due to their sensitivity to pasteurization (Eneroth et al., 2000; FDA, 2011). As Pseudomonas population in raw buffalo milk significantly increased between 24 and $48 \mathrm{~h}$, it appears that optimal processing conditions would include pasteurization of the milk within $24 \mathrm{~h}$ of collection to prevent the overgrowth of Pseudomonas and Acinetobacter psychrotrophs. Although pasteurization after $24 \mathrm{~h}$ may kill these bacteria, their increased levels could allow for the release of heat-resistant lipases and proteases from those bacteria, which have also been reported to reduce milk quality and shelf-life (Quigley et al., 2013a).

In our study, both raw and pasteurized buffalo milk samples were found to be free of bacteria within the $B a$ cillus genus; however, $\sim 2 \%$ of microflora in high-quality raw milk stored for $2 \mathrm{~h}\left(\mathrm{R}_{2}\right)$ consisted of Paenibacillus. Paenibacillus was shown to be the predominant genus of bacteria present pasteurized buffalo milk after 14 and $21 \mathrm{~d}$ of storage, reaching 25 and $85 \%$ of the total microbial population, respectively. Previous studies have reported the presence of both Paenibacillus and Bacillus spp. in raw milk entering dairy processing plants (Huck et al., 2007) and that members of these genera were the dominant gram-positive spore-forming bacteria isolated from pasteurized cow milk (Huck et al., 2008). Control of Bacillus and Paenibacillus spp. is important to the dairy industry, as their endospores can survive HTST pasteurization, allowing them to persist and potentially cause milk spoilage (Huck et al., 2008). Previous work has shown that most Paenibacillus isolated from pasteurized milk have the ability to grow at low temperatures, whereas only a few Bacillus typically grow under similar conditions (Ivy

Table 3. Influence of refrigerated storage time on the change in microflora (\%) at both the phyla and genus levels in raw milk where the overall mean was greater than $1 \%$ of total bacterial composition ${ }^{1}$

\begin{tabular}{|c|c|c|c|c|c|}
\hline Item & $\mathrm{R}_{2}$ & $\mathrm{R}_{24}$ & $\mathrm{R}_{48}$ & $\mathrm{R}_{72}$ & $P$-value \\
\hline \multicolumn{6}{|l|}{ Phylum } \\
\hline Firmicutes & $42.50 \pm 9.68^{c}$ & $80.36 \pm 5.15^{\mathrm{a}}$ & $57.30 \pm 7.69^{\mathrm{b}}$ & $32.83 \pm 5.24^{\mathrm{c}}$ & 0.000 \\
\hline Proteobacteria & $43.07 \pm 16.50^{\mathrm{b}}$ & $14.00 \pm 3.94^{\mathrm{c}}$ & $35.13 \pm 4.95^{\mathrm{b}}$ & $64.60 \pm 6.16^{\mathrm{a}}$ & 0.001 \\
\hline Bacteroidetes & $2.87 \pm 2.11^{\mathrm{a}}$ & $2.07 \pm 1.64^{\mathrm{a}}$ & $1.83 \pm 0.71^{\mathrm{a}}$ & $1.13 \pm 1.29^{\mathrm{a}}$ & 0.601 \\
\hline \multicolumn{6}{|l|}{ Genus } \\
\hline Lactococcus & $8.20 \pm 2.27^{\mathrm{c}}$ & $38.60 \pm 7.02^{\mathrm{a}}$ & $22.50 \pm 6.76^{\mathrm{b}}$ & $11.17 \pm 2.47^{\mathrm{c}}$ & 0.000 \\
\hline Pseudomonas & $4.93 \pm 0.81^{\mathrm{c}}$ & $3.63 \pm 1.30^{\mathrm{c}}$ & $17.20 \pm 4.53^{\mathrm{b}}$ & $51.00 \pm 1.87^{\mathrm{a}}$ & 0.000 \\
\hline Acinetobacter & $1.40 \pm 0.36^{\mathrm{b}}$ & $2.27 \pm 0.57^{\mathrm{b}}$ & $3.60 \pm 1.56^{\mathrm{b}}$ & $11.23 \pm 4.25^{\mathrm{a}}$ & 0.003 \\
\hline Enhydrobacter & $2.30 \pm 0.26^{\mathrm{bc}}$ & $4.37 \pm 1.80^{\mathrm{ab}}$ & $5.20 \pm 1.28^{\mathrm{a}}$ & $1.80 \pm 0.52^{\mathrm{c}}$ & 0.019 \\
\hline Corynebacterium & $3.23 \pm 0.75^{\mathrm{a}}$ & $2.00 \pm 0.52^{\mathrm{b}}$ & $1.10 \pm 0.56^{\mathrm{bc}}$ & $0.20 \pm 0.17^{\mathrm{c}}$ & 0.001 \\
\hline
\end{tabular}

${ }^{\mathrm{a}-\mathrm{c}}$ Mean values within a row that have a different superscript differ by $P<0.05$.

${ }^{1}$ Mean percentages were determined from the metagenomic analysis of 3 separate raw milk samples at each time point $\left(\mathrm{R}_{2}: 2 \mathrm{~h} ; \mathrm{R}_{24}: 24 \mathrm{~h} ; \mathrm{R}_{48}\right.$ : $\left.48 \mathrm{~h} ; \mathrm{R}_{72}: 72 \mathrm{~h}\right)$. 


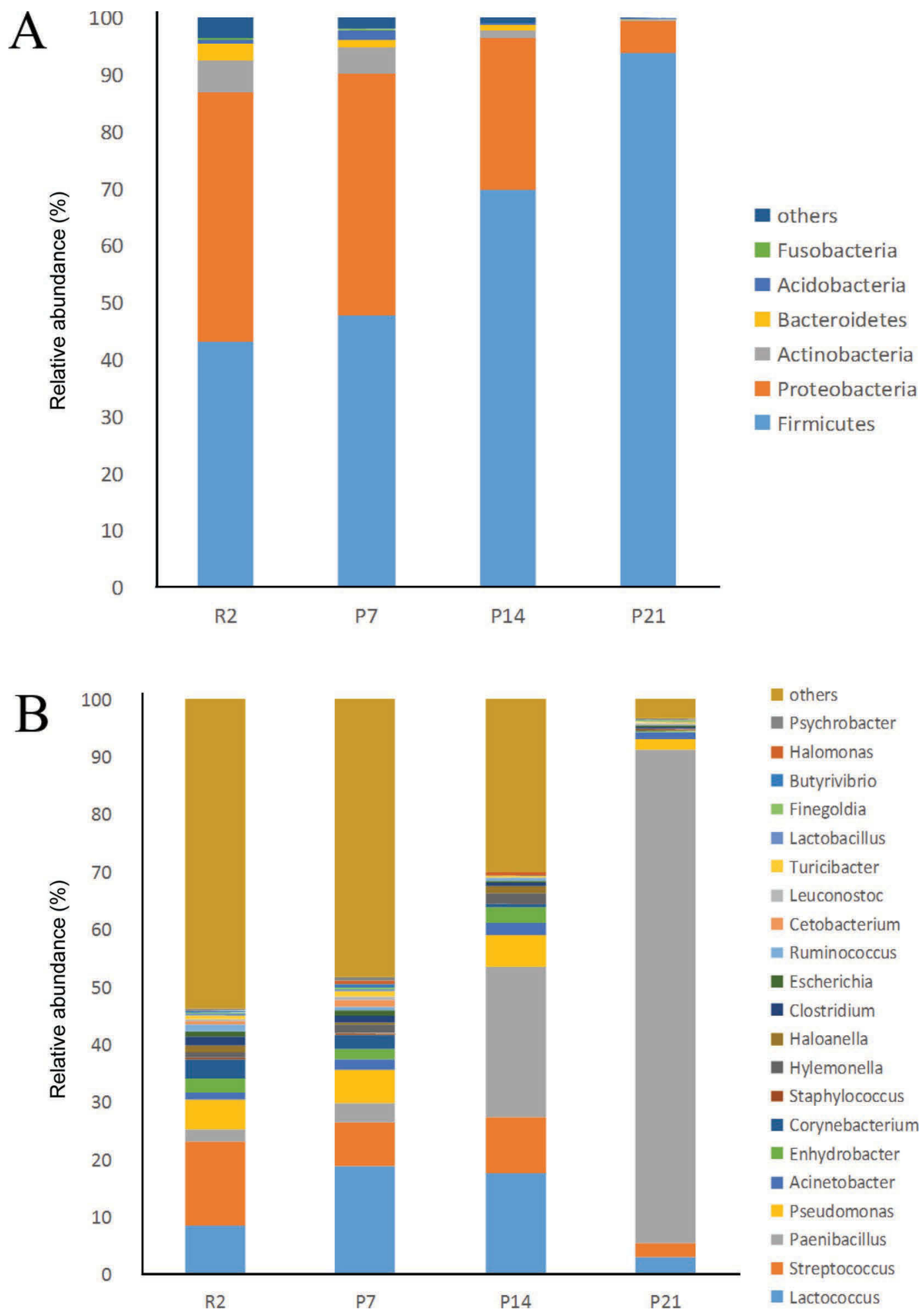

Figure 3. Composition of the indigenous microflora, at both the phyla (A) and genus (B) levels, in pasteurized milk stored at refrigerated temperature. Data represent the mean percentages from the metagenomic analysis of 3 separate raw milk samples. $R_{2}=$ raw milk samples stored for $2 \mathrm{~h}, \mathrm{P}_{7}=$ pasteurized milk samples stored for $7 \mathrm{~d}, \mathrm{P}_{14}=$ pasteurized milk samples stored for $14 \mathrm{~d}, \mathrm{P}_{21}=$ pasteurized milk samples stored for $21 \mathrm{~d}$. 
et al., 2012). Hence, Bacillus spp. have been shown to represent a predominant population in the early shelf-life of pasteurized milk (7 d), with Paenibacillus spp. becoming the predominant bacteria, representing over $95 \%$ of the population during longer storage times (10 d; Ranieri and Boor, 2010). In fact, it has been reported that PCR-based testing of raw milk for the presence of Paenibacillus spp. may assist in predicting the shelf-life performance of pasteurized fluid milk products (Ranieri et al., 2012). Our results identified Paenibacillus in the raw milk collected for transport and showed it was the predominant bacterial genus found in pasteurized buffalo milk stored for $21 \mathrm{~d}$. This suggests they may play a significant role in the spoilage of pasteurized buffalo milk. Although they represented the predominant bacterial genus in stored pasteurized milk, the population of Paenibacillus did not increase during the storage of raw buffalo milk, suggesting that other constituents of the raw milk population prevented their outgrowth. As seen with bovine milk, the results from our study suggest that technologies need to be developed for eliminating gram-positive spore-formers from raw buffalo milk to extend the shelf life of dairy products produced using pasteurized buffalo milk.

A significant population of lactococci and streptococci was identified within the raw milk microflora after 2 $\left(\mathrm{R}_{2}\right)$ and $24 \mathrm{~h}\left(\mathrm{R}_{24}\right)$ of storage. The presence of lactic acid bacteria with raw milk is well established, and they have been investigated for their potential to improve human or animal health by the production of natural antimicrobials or other probiotic-associated traits (i.e., antihypertensive activity; Quigley et al., 2013b). More recently, the isolation of potential probiotic bacteria has been described from dairy foods produced with water buffalo milk (Jeronymo-Ceneviva et al., 2014), sug- gesting that the raw milk from Chinese water buffalo may be a source for novel probiotic bacteria. Further studies should look at the potential for isolating these beneficial bacteria from raw buffalo milk that has been stored for no more than $24 \mathrm{~h}$ when the population of lactic acid bacteria appears abundant (Table 3).

\section{CONCLUSIONS}

This report describes the diverse bacterial community found in raw and pasteurized buffalo milk from Guang-Xi, China. The composition for the microbial community at the phylum and genus levels was characterized in both raw and pasteurized milk samples by high-throughput sequencing to demonstrate the population shifts which occur during long-term storage at refrigeration temperature $\left(\leq 4^{\circ} \mathrm{C}\right)$. Results showed that bacteria within the Lactococcus and Streptococcus genera dominated the raw milk microflora when stored for up to $24 \mathrm{~h}$, but extended storage resulted in an outgrowth of Pseudomonas and Acinetobacter, which comprised more than $60 \%$ of the total population at 72 h. In pasteurized milk, Paenibacillus dominated the microbial population after $21 \mathrm{~d}$ of storage. Although the population changes differed between raw and pasteurized milks, the predominant bacterial populations identified after prolonged storage were psychrotrophic microorganisms commonly associated with the spoilage of dairy products. Whereas pasteurization appeared sufficient for eliminating contaminants from the Pseudomonas and Acinetobacter genera, this study demonstrated the need for developing novel methods or technologies for controlling the proliferation of Paenibacillus to extend the shelf-life of pasteurized buffalo milk products.

Table 4. Influence of refrigerated storage time on the change in microflora (\%) at both the phyla and genus levels in pasteurized milk, where the overall mean was greater than $1 \%$ of the total bacterial composition ${ }^{1}$

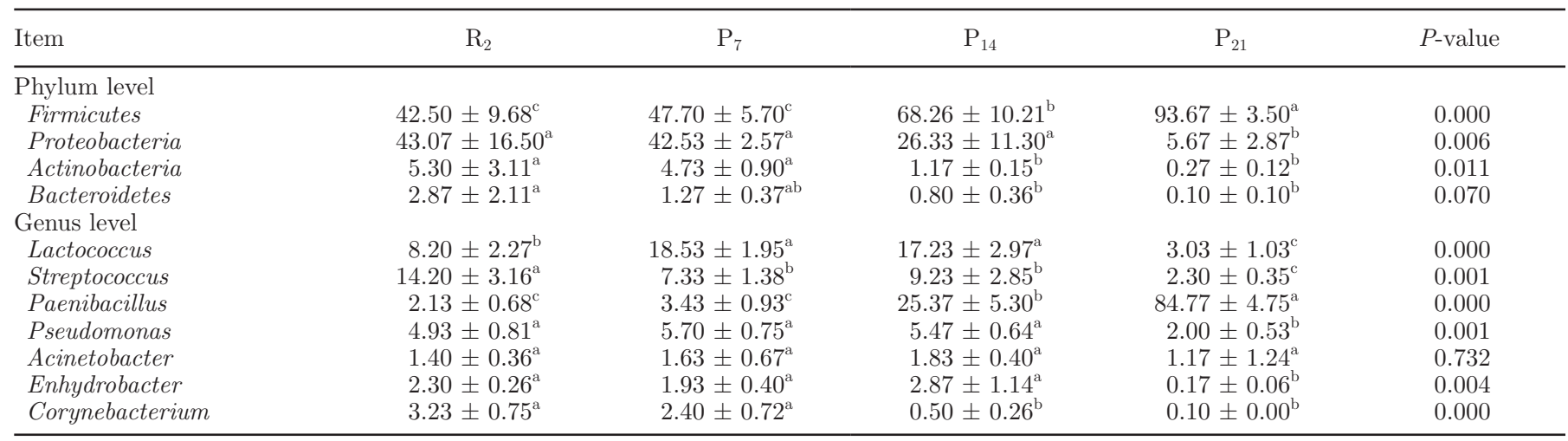

\footnotetext{
${ }^{\mathrm{a}-\mathrm{c}}$ Mean values within a row that have a different superscript differ by $P<0.05$.

${ }^{1}$ Mean percentages were determined from the metagenomic analysis of 3 separate pasteurized milk samples at each time point $\left(\mathrm{P}_{7}: 7\right.$ d; $\mathrm{P}_{14}: 14$ $\mathrm{d} ; \mathrm{P}_{21}: 21 \mathrm{~d}$ of storage). $\mathrm{R}_{2}$ : raw milk samples stored for $2 \mathrm{~h}$.
} 


\section{ACKNOWLEDGMENTS}

Financial support for this study was through the state science and technology support program of the 12th five-year plan (2013BAD18B12-3) and basic research funds of Guangxi Buffalo Research Institute (1404006; Guangxi, P. R. China).

\section{REFERENCES}

Caporaso, J. G., J. Kuczynski, J. Stombaugh, K. Bittinger, F. D. Bushman, E. K. Costello, N. Fierer, A. Gonzalez Pena, J. K. Goodrich, J. I. Gordon, G. A. Huttley, S. T. Kelley, D. Knights, J. E. Koenig, R. E. Ley, C. A. Lozupone, D. McDonald, B. D. Muegge, M. Pirrung, J. Reeder, J. R. Sevinsky, P. J. Turnbaugh, W. A Walters, J. Widmann, T. Yatsunenko, J. Zaneveld, and R. Knight. 2010. QIIME allows analysis of high-throughput community sequencing data. Nat. Methods 7:335-336.

Caporaso, J. G., C. L. Lauber, W. A. Walters, D. Berg-Lyons, C. A. Lozupone, P. J. Turnbaugh, N. Fierer, and R. Knight. 2011. Global patterns of $16 \mathrm{~S}$ rRNA diversity at a depth of millions of sequences per sample. Proc. Natl. Acad. Sci. USA 108(Suppl. 1):4516-4522.

Champagne, C. P., R. R. Laing, D. Roy, A. A. Mafu, and M. W. Griffiths. 1994. Psychrotrophs in dairy products: Their effects and their control. Crit. Rev. Food Sci. Nutr. 34:1-30.

De Jonghe, V., A. Coorevits, K. Van Hoorde, W. Messens, A. Van Landschoot, P. De Vos, and M. Heyndrickx. 2011. Influence of storage conditions on the growth of Pseudomonas species in refrigerated raw milk. Appl. Environ. Microbiol. 77:460-470.

Delbès, C., L. Ali-Mandjee, and M. C. Montel. 2007. Monitoring bacterial communities in raw milk and cheese by culture-dependent and-independent 16S rRNA gene-based analyses. Appl. Environ. Microbiol. 73:1882-1891.

Delgado, S., C. T. Rachid, E. Fernández, T. Rychlik, A. Alegria, R. S. Peixoto, and B. Mayo. 2013. Diversity of thermophilic bacteria in raw, pasteurized and selectively-cultured milk, as assessed by culturing, PCR-DGGE and pyrosequencing. Food Microbiol. $36: 103-111$.

Edgar, R. C. 2013. UPARSE: Highly accurate OUT sequences from microbial amplicon reads. Nat. Methods 10:996-998.

Eneroth, A., S. Ahrne, and G. Molin. 2000. Contamination routes of gram-negative spoilage bacteria in the production of pasteurized milk, evaluated by randomly amplified polymorphic DNA (RAPD). Int. Dairy J. 10:325-331.

Ercolini, D., F. Russo, I. Ferrocino, and F. Villani. 2009. Molecular identification of mesophilic and psychrotrophic bacteria from raw cow's milk. Food Microbiol. 26:228-231.

FDA. 2011 revision. Grade "A" pasteurized milk ordinance, p 8-31. No. 229. Public Health Service, Food and Drug Administration (FDA), US Department of Health and Human Services, Washington, DC.

Fonseca, C. R., K. Bordin, A. M. Fernandes, C. E. C. Rodrigues, C. H. Corassin, A. G. Cruz, and C. A. F. Oliveira. 2013. Storage of refrigerated raw goat milk affecting the quality of whole milk powder. J. Dairy Sci. 96:4716-4724.

Hantsis-Zacharov, E., and M. Halpern. 2007. Chryseobacterium haifense sp. nov., a psychrotolerant bacterium isolated from raw milk. Int. J. Syst. Evol. Microbiol. 57:2344-2348.

Huck, J. R., B. H. Hammond, S. C. Murphy, N. H. Woodcock, and K. J. Boor. 2007. Tracking spore-forming bacterial contaminants in fluid milk-processing systems. J. Dairy Sci. 90:4872-4883.

Huck, J. R., M. Sonnen, and K. J. Boor. 2008. Tracking heat-resistant, cold-thriving fluid milk spoilage bacteria from farm to packaged product. J. Dairy Sci. 91:1218-1228.
Ivy, R. A., M. L. Ranieri, N. H. Martin, H. C. den Bakker, B. M. Xavier, M. Wiedmann, and K. J. Boor. 2012. Identification and characterization of psychrotolerant sporeformers associated with fluid milk production and processing. Appl. Environ. Microbiol. 78:1853-1864.

Jeronymo-Ceneviva, A. B., A. T. de Paula, L. F. Silva, S. D. Todorov, B. D. Franco, and A. L. Penna. 2014. Probiotic properties of lactic acid bacteria isolated from water-buffalo mozzarella cheese. Probiotics Antimicrob. Proteins 6:141-156.

Magoč, T., and S. Salzbert. 2011. FLASH: Fast length adjustment of short reads to improve genome assemblies. Bioinformatics 27:2957-2963.

Mankai, M., M. Boulares, O. B. Moussa, R. Karoui, and M. Hassouna 2012. The effect of refrigerated storage of raw milk on the physicochemical and microbiological quality of Tunisian semihard Goudatype cheese during ripening. Int. J. Dairy Technol. 65:250-259.

Quigley, L., R. McCarthy, O. O'Sullivan, T. P. Beresford, G. F. Fitzgerald, R. P. Ross, C. Stanton, and P. D. Cotter. 2013a. The microbial content of raw and pasteurized cow milk as determined by molecular approaches. J. Dairy Sci. 96:4928-4937.

Quigley, L., O. O'Sullivan, T. P. Beresford, R. P. Ross, G. F. Fitzgerald, and P. D. Cotter. 2012. A comparison of methods used to extract bacterial DNA from raw milk and raw milk cheese. J. Appl. Microbiol. 113: 96-105.

Quigley, L., O. O'Sullivan, C. Stanton, T. P. Beresford, R. P. Ross, G. F. Fitzgerald, and P. D. Cotter. 2013b. The complex microbiota of raw milk. FEMS Microbiol. Rev. 37:664-698.

Raats, D., M. Offek, D. Minz, and M. Halpern. 2011. Molecular analysis of bacterial communities in raw cow milk and the impact of refrigeration on its structure and dynamics. Food Microbiol. $28: 465-471$

Ranieri, M. L., and K. J. Boor. 2010. Tracking and eliminating sporeformers in dairy systems. Aust. J. Dairy Technol. 65:74-80.

Ranieri, M. L., J. R. Huck, M. Sonnen, D. M. Barbano, and K. J. Boor. 2009. High temperature, short time pasteurization temperatures inversely affect bacterial numbers during refrigerated storage of pasteurized fluid milk. J. Dairy Sci. 92:4823-4832.

Ranieri, M. L., R. A. Ivy, W. R. Mitchell, E. Call, S. N. Masiello, M. Wiedmann, and K. J. Boor. 2012. Real-time PCR detection of Paenibacillus spp. in raw milk to predict shelf life performance of pasteurized fluid milk products. Appl. Environ. Microbiol. 78:5855-5863.

Reche, N. L. M., A. T. Neto, L. D'Ovideo, N. C. Felipus, L. C. Pereira, L. L. Cardozo, R. G. Lorenzetti, and L. C. A. Picinin. 2015. Microbial multiplication in raw milk stored in direct expansion bulk tanks. Ciênc. Rural 45:828-834.

Sanjuan, S., J. Rúa, and M. R. García-Armesto. 2003. Microbial flora of technological interest in raw ovine milk during $6 \mathrm{C}$ storage. Int. J. Dairy Technol. 56:143-148.

Sorhaug, T., and L. Stepaniak. 1997. Psychrotrophs and their enzymes in milk and dairy products: Quality aspects. Trends Food Sci Technol. 8:35-41.

Wang, Q., G. M. Garrity, J. M. Tiedje, and J. R. Cole. 2007. Naive Bayesian classifier for rapid assignment of rRNA sequences into the new bacterial taxonomy. Appl. Environ. Microbiol. 73:5261-5267.

Weber, M., J. Geißert, M. Kruse, and A. Lipski. 2014. Comparative analysis of bacterial community composition in bulk tank raw milk by culture-dependent and culture-independent methods using the viability dye propidium monoazide. J. Dairy Sci. 97:6761-6776.

Zhang, R., W. Huo, W. Zhu, and S. Mao. 2015. Characterization of bacterial community of raw milk from dairy cows during subacute ruminal acidosis challenge by high-throughput sequencing. J. Sci. Food Agric. 95:1072-1079. 